\title{
Introduction: How did we get here?
}

The Rockettes is a well-known precision dance company performing out of Radio City Music Hall in New York City. Every Christmas season since 1932, the company performed Radio Music City Hall's famed 'Christmas Spectacular' four-to-six shows a day, seven days a week, with its bestknown routine being an eye-high leg kick in perfect unison with a chorus line included at the end of every performance. The magic of America's favourite holiday show was complete with the Rockettes' performance to a 36-piece live orchestra. However, in 2005, in the course of a failed standard contractual negotiation between the musicians' union and the producers of the Christmas Spectacular, the show producers turned their musicians away when they showed up to perform for the show and opted instead for recorded music to back the show's performance. ${ }^{1}$ By doing so, the producers of the Christmas Spectacular determined, and to a large extent diluted, the cultural experience that their patrons experienced, by replacing a full orchestra with canned, pre-recorded music. While nothing in the law prohibits the producers from doing so, surely there has to be some moral obligation that is owed by the producers to the musicians and the patrons of the Christmas Spectacular. Shouldn't the producer of a public performance have an ethical obligation to provide the best cultural experience possible for society because social and cultural progress depend on a good faith provision of creative works?

The law appears to not think that producers of creative works are required to abide by any ethical obligations in their provision of creative works for society. In a landmark 2005 case, for example, Metro-GoldwynMayer Studios, Inc. v. Grokster, Ltd, the Supreme Court of the United States unanimously decided that a software distributor whose free, downloadable software products allowed its users to share digital files through the Internet, including copyrighted audio and video files, without the authorisation of the copyright owner, could be contributorily liable for copyright-infringing activities. ${ }^{2}$ The court declared that if it could be shown

\footnotetext{
${ }^{1}$ Jaclyn Schiff, 'Radio City Opts for Canned Music: Spurns Musicians' Offer to Play Christmas Spectacular After Walkout', available at: www.cbsnews.com/stories/2005/11/03/ entertainment/main1006028.shtml.

2545 U.S. 913.
} 
that a distributor intended to promote unauthorised uses of copyrighted works by 'a clear expression or other affirmative steps taken to foster infringement', that distributor would be liable for inducing the infringement of copyrighted works by its users. In this case, the provider of creative works to society - a group of copyright owners comprising motion picture studios, recording companies, songwriters, and music publishers - successfully argued that Grokster Ltd and StreamCast Networks, had induced their users' infringement in several ways: by deliberately attempting to capture the market for illegal file-sharing software left by the demise of Napster; failing to develop tools to diminish infringing activities using their software; and building their revenue model on advertising sales that would increase significantly with high-volume infringing usages. 'The unlawful objective' for the distribution of the software, said Justice Souter, 'is unmistakable'.

This case represents a significant victory for the entertainment industry in its persistent fight to maintain control over social uses of literary and artistic works. But the same question about ethics resurfaces again here. Should copyright owners be allowed to prevent the sharing of creative works when technology exists to allow users to do so? Is the distribution of software that allow creative works to be shared digitally inherently wrong? Should technology manufacturers distributing technology, even with the intention to actively induce use of copyrighted content, be considered to have engaged in illegal behaviour? Is the sharing of creative works illegal because it is inherently harmful to social and cultural progress? Or is sharing of creative works illegal simply because the legal system protects economic rights of a copyright owner instead of holding the producer of creative works morally obligated to provide the best cultural experience for society through the production and use of such works? These are difficult questions and the inherent friction within the copyright system as its laws try to steer a difficult path between protecting private economic rights over literary and artistic works, on the one hand, and facilitating the progress of science and the arts for society's benefit, on the other is evident in this case. The interests in literary and artistic works are varied and often sharply at odds with each other. Copyright owners, for their part, seek possessory control over creative works as a form of property because exclusive control creates the scarcity necessary for the successful commercialisation of literary and artistic works. Users of creative works, on the other hand, seek access to these works for many reasons, including entertainment, research and development, and education. And the authors or creators of literary and artistic works seek recognition,

3545 U.S. 913, 940 (2005). 
monetary payment, and respect for their creative talents as and when they publish and disseminate their work to the public. Currently, these different and competing interests in literary and artistic works are balanced against each other without any principled or normative standard for resolution. The original purpose of the United States copyright system, as set out in the Constitution, is clearly singular: to promote the progress of science by granting authors exclusive rights over literary and artistic works to encourage creative production for society's benefit. While this is clearly a desirable goal, the grant of private exclusive rights over these works may unnecessarily limit society's ability to access works in the public domain as copyright owners persist in their fight to assert possessory control over literary and artistic works. To James Boyle, this fight is reminiscent of the enclosure movement in England, where over the course of 400 years, land held in common was converted to private property and enclosed by the state. $^{4}$

Yet, this book argues, exclusive rights and public goals need not be as antithetical as current thought about the copyright system suggests that they are. One such school of thought, steeped in the tradition of law and economics, sees the grant of exclusive rights over literary and artistic works as an encouragement for creators and their publishers to engage in creative production. The belief that creators will be able to recover the cost of producing their work only if the law ensures that the market price for the work will not be driven down by piracy resonates well with copyright owners and serves to justify copyright protection and exclusive rights. Without copyright protection, a copier who bears little or no investment risk in production may unfairly profit from the success of well-received works and prevent creators and their publishers from recovering the costs of production from the market. A second and contradictory train of thought, premised instead on libertarian ideals of individual freedom, argues that the public goal of progress in science and the arts can be attained only by putting limitations on a copyright owner's proprietary control over uses of literary and artistic works, thereby preserving the public domain and conserving raw materials needed by other creators in the creative process. As Jessica Litman reminds us, authorship often involves the translation and recombination of existing works rather than an act of 'creating Aphodrite from the foam of the sea', a metaphor symbolising the romantic notion of a heroic, solitary author creating wholly original work through a sudden stroke of genius. ${ }^{5}$ Because in fact the author or creator of a work is never free from influence by surrounding

\footnotetext{
4 James Boyle, The Public Domain (New Haven, CT: Yale University Press, 2008), p. 42.

5 Jessica Litman, 'The Public Domain' (1990) 39 Emory L.J. 965, 967.
} 
literature and works of art, extensive property rights may restrict the very act of creativity necessary for progress. And as Lord Mansfield eloquently pointed out more than two hundred years ago, extreme care must be taken to make sure that 'the world may not be deprived of improvements, nor the progress of arts be retarded' by the 'reward [for] ingenuity and labour'. ${ }^{6}$

Most of the relevant literature and commentary on copyright law has focused on the apparent conflict between the grant of property rights to encourage creative production and the necessity of ensuring public access to creative works to oil the wheels of progress. ${ }^{7}$ As a result, most have viewed these conflicts as the result of flaws of the legal system that are in need of reform, or at the very least in need of being treated with grave caution, particularly now that the Internet and digital technologies have produced profound changes in society's ability to use and modify literary and artistic works as a legitimate form of free expression. ${ }^{8}$ It may be that copyright scholars and practitioners have been too uncritical in our acceptance of the inadequacies of the legal system in dealing with technological progress that offers previously undreamed-of advancements not only in science and the useful arts, but also in society, culture, and political discourse. This complacent acceptance of the failings of the copyright system and the tendency to call for legal reform is a position often embraced in successive waves of advancements in technological development. In 1966, for instance, Benjamin Kaplan began his James S. Carpentier Lecture at Columbia Law School by saying that:

as a veteran listener at many lectures by copyright specialists over the past decade, I know it is almost obligatory for a speaker to begin by invoking the

\footnotetext{
Sayre v. Moore 1 East 361, 102 Eng. Rep. 139 (K.B. 1785).

See e.g. Mark A. Lemley, 'Property, Intellectual Property, and Free Riding' (2005) 83 Tex. L. Rev. 1031 (arguing that property rights do not entitle the property owner to fully internalise positive externalities created by an activity); Stewart E. Sterk, 'Intellectualizing Property: The Tenuous Connection Between Land and Copyright' (2005) 83 Wash. U.L.Q. 417 (cautioning against the use of real property concepts to intellectual works where rights are provided as an incentive to create); Shubha Ghosh, 'Deprivatizing Copyright' (2003) 54 Case W.L. Rev. 387 (arguing that copyright should be deprivatised in order to achieve the public good purpose of the institution); Glynn S. Lunney, Jr., 'Reexamining Copyright's Incentives-Access Paradigm' (1996) 49 Vand. L. Rev. 483 (arguing that the incentives-access paradigm used to balance economic rights against public interest is an improper tool for defining copyright's limits and should be replaced by allocative-efficiency); Howard B. Abrams, 'Originality and Creativity in Copyright Law' (1992) 55 SPG Law \& Contemp. Probs. 3 ( seeing copyrightability as a balance that is drawn between the competing claims of the copyright owner and copyright user).

${ }^{8}$ For an example of the first of these perspectives, see Pamela Samuelson, 'Preliminary Thought on Copyright Reform' (2007) Utah L. Rev. 551; for the second, see Neil Weinstock Netanel, 'Copyright and a Democratic Civil Society' (1996) 106 Yale L.J. 283.
} 
"communications revolution" of our time, then to pronounce upon the inadequacies of the present copyright act, and finally to encourage all hands to cooperate in getting a Revision Bill passed. ${ }^{9}$

Whether a revision of the copyright system in response to the advent of the information age is warranted is a discussion to be undertaken outside the pages of this book, whose purpose is not to argue with either line of thinking or to criticise the copyright system for its alleged failings in achieving a neat balance between private rights in and public access to literary and artistic works. Rather, its purpose is to contribute a third thread of thought to this conversation by introducing a normative analysis on the nature of property rights and economic incentives that might bridge the gap between the wants of authors and creators, their publishers and distributors, and the larger society with the larger institutional goal of ensuring progress in science and the arts. Despite the lack of confidence of many scholars in the system, this book argues that a strong copyright system has substantial merit, and makes the case for a robust, rather than weakened, copyright system that brings together and protects different values surrounding the creation, dissemination, and use of literary and artistic works. Sustained creativity, it contends, is best achieved by upholding rather than undermining individual legal rights in literary and artistic works. By grasping the different nuances of property rights and economic privileges and deepening our understanding of the different kinds of entitlements and where they might fit on a rights and privileges scale, it becomes obvious that individual rights are unlikely to derail the natural progress of science and the useful arts.

A robust copyright system that will further the progress of the sciences and useful arts will, the following chapters assert, adapt to its society at any given point in history; will direct the creative and productive activities of authors, industry, and users toward the broader goals of educational, cultural, and educational growth; and will be able to adjust its institutional framework to embrace technological changes to allow the sciences and the useful arts to progress in the direction of basic human flourishing. This book maintains that if copyright laws are sufficiently robust, the legal system will promote, rather than impede, such progress. Legal reform to the copyright system, if any is to be undertaken, must, it argues, emanate from a deeper and more nuanced appreciation of the nature of property rights and economic privileges that are consistent with the goals of progress rather than a hasty inclination toward change.

Benjamin Kaplan, An Unhurried View of Copyright (New York: Columbia University Press, 1967), p. 1. 
Fundamentally, as will be established in the following chapters, property rights are about establishing boundaries through exclusive control of resources that are limited. How easily this conception fits into the copyright system is arguable. Creative production and progress in science and the arts both depend on the same thing: the ability to access and use materials from the common storehouse of human knowledge. As suggested above, new generations of authors and creators must be able to use collective knowledge, research findings, and documented experiences to guide their own explorations and experiments in creating new insights and materials for society. If this fails to happen, the development in culture, better education, or economic growth that we all seek will always be elusive. Boyle and Litman are right to be concerned that granting stronger property rights to copyright owners runs the risk of preventing society from accessing the information and knowledge needed to further progress in the sciences and the arts. Even if reformers should feel compelled to draw boundaries between private rights and the public domain, they will not be easy boundaries to draw, especially if the purpose for drawing these boundaries is to allocate entitlements between copyright owners and society through a system of proprietary rights and exclusive control. Furthermore, any carefully drawn boundary is likely to crumble with the introduction of every new technology that enables greater user interaction with creative works, which in turn threatens a copyright owner's ability to commercialise works and recover the investment costs of production. Digital downloads of content through peer-to-peer technology in the Grokster case is just one such example. Since copyright is, as Paul Goldstein says, 'technology's child from the start', we can expect boundaries between private rights and public interests to be continually redefined. ${ }^{10}$

Perhaps, then, the ultimate goal of the copyright system is not to draw boundaries or make creative works exclusive through a system of proprietary rights and exclusive control but just the reverse: to build connections and be inclusive of different interests in creative works. As this book suggests, the copyright system may instead be about one human activity - authorship - and about one idea - connecting authors with their readers. In such an equation, property rights and economic privileges in literary and artistic works support the act of authorship in order to connect creators with their consumers and are not ends in themselves. Rather than securing private interests, these entitlements, would serve an institutional goal: encouraging authorship of literary and artistic works to further the

${ }^{10}$ Paul Goldstein, Copyright's Highway (Stanford, CA: Stanford University Press, 2003), p. 21. 
progress of science and the arts in society. Thinking about the copyright system in such a way may require us to question our assumptions and change our perspectives on what a property right means and the kind of entitlements it entails on an objective and normative level. But this is more than an intellectual discourse within academic circles. Choosing to see the copyright system through the prism of opportunity rather than of failure can make it possible for us to direct our energies toward finding ways to sustain creative production in the best interest of society as a whole.

The notion that the copyright system is intended to further authorship by connecting authors with their readers is, of course, not original to this book but a penetrating idea first raised by an intellectual giant in the field, Paul Goldstein. For Goldstein, 'copyright, in a word, is about authorship', by which he means 'authors communicating as directly as circumstance allows with their intended audiences.' 11 This book's central theme that copyright laws should promote authorship of all sorts of artistic works that involve the contribution of autonomous individuals and connect authors with their readers to fulfil the constitutional goals of progress builds upon Goldstein's ideas. To build its case for a robust copyright system that embodies the norms of creativity and individual authorial expression, the book relies heavily on the path-breaking work of Lawrence Lessig on the potential industry abuses of copyright and their long-term effects on culture, science, and individual freedom and on Margaret Radin's theory of personhood as a basis for property rights. Where this book departs from their analyses is its claim that rights over literary and artistic works should not be considered a possessory right that justifies exclusive control but instead as rights that, in protecting individual expectations, support a larger institutional goal.

To construct a new normative theory of inclusiveness for a copyright system that holds the progress of science and the useful arts as its institutional goal, this book attempts to identify a set of moral and ethical principles that could guide the use and production of literary and artistic works by authors, publishers, and users toward social and cultural advancement. Although the jurisprudential works of Hans Kelsen, H.L.A. Hart, Lon Fuller, Joseph Raz, and John Finnis have provided some suggestive directions for this project and served as a foundation for evaluating the proper role of the law in upholding morals in society, ultimately the analysis in the following pages is most indebted to the thinking of legal and moral philosophers within the social contract and political philosophy traditions in its attempt to build a normative social order that would guide the players in the copyright system toward a shared and singular goal. As will

${ }^{11}$ Paul Goldstein, 'Copyright' (1991) 38 J. Copyright Soc'y 109. 
become clear in the following chapters, the political and moral philosophy underlying communal obligations so cogently developed by John Rawls and Ronald Dworkin's argument that every legal system contains clearly identifiable principles of morality and ethics has been instrumental in shaping this book's vision of a copyright system as a legal institution with an ethical goal or moral end. Of course, no normative theory of property rights would also be complete without reference to the writings of John Locke and Wilhelm Hegel. Their influence can be found in this book's argument that the act of appropriation that forms the basis for ownership rights over creative works creates an expectation for possessory control that is inimical to progress of science and the arts. Using creation rather than appropriation as the basis for ownership rights, it asserts, creates a different set of expectations and obligations more consistent with a political and moral theory of justice that would require authors, publishers, and individuals in society to work together collaboratively to support the common institutional goal of progress.

Such progress in the sciences and the arts is path dependent, in that (as economist Nathan Rosenberg notes) 'the most probable directions for future growth in knowledge can only be understood within the context of the particular sequence of events which constitutes the history of the system'. ${ }^{12}$ Thus the decisions of our past on the copyright system have led us to where we are today, and where we go in the future depends on what we decide to do with our system of laws today. Part I of this book begins with a description of today's community-based production of literary and artistic works, especially as it draws from multiple conversations among various collaborative networks over the Internet. As discussed in these two chapters, society has increasingly come to expect access to literary and artistic works not only for entertainment and educational purposes but for facilitating greater participation in political and civic discourses. The connectivity of the Internet and easy availability of digital technologies has transformed the users of creative works from passive recipients and consumers of the works of far-removed, remote, isolated, and disengaged producers into active authors and creators themselves often seeking new ways to engage in creative and authentic forms of expression. These new voices of authentic authorship, this book argues, must be provided access to a space for rich and uncensored expression.

As discussed in Part II, these are not the social conditions that the earliest copyright laws were intended or equipped to deal with. Censorship and trade regulation, not the encouragement of creativity, were the initial

12 Nathan Rosenberg, Inside the Black Box: Technology, Economics, and History (Cambridge: Cambridge University Press, 1994), p. 10. 
purposes for copyright regulation. Even though progress in science and the arts was explicitly expressed as a goal in the American Constitution in 1787, it would have been impossible for its framers to anticipate the current state of literary and artistic production. Thus these three chapters explore our past and how the law's decisions about the role of the author, the nature of literary rights vis-à-vis statutory copyright, and their relationship with technological change have led us to the literary and artistic culture of today.

After examining the present and the past of copyright law, Part III turns its focus to the future, laying out a proposal for conceptualising the copyright system as a legal institution to connect authors with their readers and presenting a theory of property rights that is based on an act of creation and introduces the idea of authorship, connection, and inclusiveness into the copyright system. Although the focus of the book to this point has been the Anglo-American tradition of copyright, the final chapter turns to address other copyright jurisdictions and applies the preceding analysis to the area of international copyright.

The intention of this book is to introduce a new perspective on the various rights and obligations that authors, publishers, and society should and must bear in relation to the production and use of literary and artistic works if the legal system is serious about nurturing scientific and artistic progress through the creativity of these players. In the final analysis, it is intended to change how we think about the copyright system as a legal institution, its role in society, and its effect on progress and help jurists and scholars make decisions that will realise sustainable progress in the sciences and the arts for the benefit of the communities of which we are a part. 
Alina $\mathrm{Ng}-9781849807821$ 